\title{
ПРИМЕНЕНИЕ $\omega$-АМИНОКИСЛОТ ДЛЯ ОБЪЕДИНЕНИЯ ТАРГЕТНЫХ МОЛЕКУЛ
}

\author{
Д.С. Новикова, В.Г. Трибулович \\ НИЛ «Молекулярная фармакология», Санкт-Петербургский государственный \\ технологический институт (технический университет), \\ 190013, Россия, Санкт-Петербург, Московский пр., 26.
}

DOI: 10.19163/MedChemRussia2021-2021-45

E-mail: dc.novikova@gmail.com

Разработка таргетных соединений является одним из основных направлений медицинской химии. В рамках этой концепции особое место занимают мультитаргетные агенты, то есть соединения, обладающие сродством к нескольким сходным биологическим мишеням, эффект воздействия на которые носит однонаправленный характер. Это может быть достигнуто путем определения компромиссной структуры за счет тонкого варьирования фармакофоров, что крайне трудно реализовать на практике.

Другим способом получения мультитаргетных соединений является объединение нескольких фармакофорных фрагментов в одной молекуле. Данная идея является не новой, но свое развитие она получила в связи с разработкой концепции PROTAC (PRoteolysis TArgeting Chimeras) [1]. В клеточных условиях помимо убиквитинилирования существуют и другие критически важные посттрансляционные модификации. Данный факт предполагает возможность использования химерных молекул как инструмента, позволяющего изменять субстратную специфичность ферментов.

Нами были получены модельные химерные молекулы на основе ингибиторов MDM2 и активаторов АМФК. В качестве линкерных фрагментов использовались $\omega$-аминокислоты. Рассмотрены перспективы использования аминокислот для формирования линкеров и особенности сборки химерных молекул. Показано, что $\omega$-аминокислоты являются удобным инструментом для создания химер.

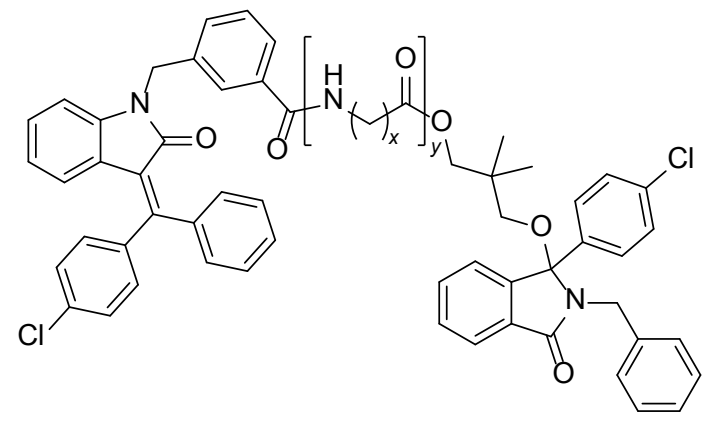

Литература

[1] S. Khan, Y. He, X. Zhang, Y. Yuan, S. Pu, Q. Kong, G. Zheng, and D. Zhou, Oncogene, 2020, 39, 4909-4924. 